\title{
Tourism in Samarinda City, East Kalimantan: Recent Status and Future Directions
}

\author{
Mardiany \\ Office of Research and Development, East Kalimantan Province, Samarinda, Indonesia
}

\begin{abstract}
Tourism in Samarinda city, East Kalimantan, has been growing significantly and provides opportunities to develop as an alternative economic earning of city government and city dwellers. It is especially important to reduce mining activity and promotes more sustainable economic activity in Samarinda. The aims of the research were to identify the tourism potentials in Samarinda and discuss the opportunities for future tourism development. Research finds that basically tourism in Samarinda city grows significantly, following the growth of tourism in East Kalimantan Province. As a capital city, the basic infrastructure and amenity to support tourism are available in numerous form. There are also tourism attractions distributed in Samarinda city, ranging from natural, cultural and man-made attraction. These provide potentiality for Samarinda city to transform the regional policy in development, with put tourism is one of the main machines for future economic growth.
\end{abstract}

Keywords: mining, sustainable tourism, tropical forest, urban development.

\section{INTRODUCTION}

In Indonesia, tourism contributes significantly in economic sectors. The GDP of tourism in Indonesia in 2015 was recorded about IDR 461.36 trillion, or equal to $4.23 \%$ of national GDP. Tourism also contributes significantly in order to increase national economic value and support jobs for local community in many regions in Indonesia. In Indonesia, statistical records on 2015 state that tourism sectors able to provide jobs for 12.16 billion of people [1]. According to scholars, tourism effective to provides opportunities to increase economy activity, especially in combating poverty and providing jobs for local community. Therefore, numerous countries in the globe provides serious attention to the tourism sectors development $[2,3,4]$.

Tropical forest ecosystems are the significant resources for tourism. It is especially important because Indonesia in country with huge forest. Tropical forest is crucial form of biodiversity, in which Indonesia was classified as megabiodiversity countries together with Brazilia and Congo. Kalimantan is home of numerous mega fauna, including Orang Utan (Pongo pygmaeus) and Bekantan (Nasalis larvatus). Tropical forest of Kalimantan is home of about 350 bird species, 150 reptile species and 15,000 plants species. Many of them are endemic to Kalimantan Island. Since 1995, more than 600 species was found,

\footnotetext{
Correspondence address:

Mardiany

Email : mardianykaltim@gmail.com

Address : Office of Research and Development, East Kalimantan Province, MT. Haryono 126, Samarinda, East Kalimantan, Indonesia
}

indicates the significant position of Kalimantan as home of global biodiversity. Kalimantan is home for 350 to 400 tribal communities with its diverse culture and language. There are also numerous indigenous knowledge exist, in which its contribution to Kalimantan's biodiversity conservation has been identified important $[5,6,7]$. These are potential resources for tourism development in Kalimantan Island.

Samarinda city in East Kalimantan has policy to put business, industry and trading as pillars for city development [8]. Basically, the city of Samarinda has uniqueness which is potential to convert as tourism attractions. It is including richness of species and ecosystem diversity as well as cultural diversity. There are also opportunities for tourist visitation due to numerous visitors has been identified made various activity in Samarinda [9]. Statistically, the trend of tourist visitation to Samarinda is similar with the trend of tourist visitation to East Kalimantan [10].

Throughout the world, trend and opportunities for tourism development lead to the city government made numerous collaboration with stakeholder, especially to increase stakeholders support in tourism development. These also implemented by city government of Samarinda. Through the collaboration, city government of Samarinda wishes to be able to increase and accelerate tourism development. Limit of the tourism development in Samarinda related to the poor of basic data related to the tourism attraction and its opportunities. There are also opportunities to increase the availability and quality of tourism accommodation. 
Samarinda is facing serious environment impact due to intensive mining [11]. There should be an alternative development approach with the objectives is increasing social and economic benefits while in the same time environment conserved. The development of sustainability tourism in Samarinda has significant positive impact to environmental conservation. There are opportunities to use tourism as a media to enhance land conservation in Samarinda, especially in pat mining area in city. The aims of the research were to identify the tourism potentials in Samarinda and discuss the opportunities for future tourism development.

\section{RESEARCH METHOD \\ Data Collection}

Research consists of two aspects, namely secondary data exploration and field observation. Secondary data exploration was done through document exploration, compilation and analysis to generate the information regarding tourism status in Samarinda. Secondary data was collected from numerous institutions, including Statistical Office of Samarinda City, Office of Tourism, and Office of Regional Planning and Development.

\section{Data Processing and Analysis}

Field work was done by visiting the entire mentioned tourism object in Samarinda city. Each object was visited and mapped using Global Positioning System (GPS) equipment. The gathered data was collected and stored in computer system. Coordinate point was involved in digital map of Samarinda city and analyzed using software ArcGis 10.1.

\section{RESULT AND DISCUSSION Tourism in Samarinda}

Literature and document survey confirm that tourism sector in Samarinda grows significantly (Fig.1). These data seems to be similar with tourism grows in East Kalimantan. This trend also similar with the national and global tourism grows, indicated that tourism is important and has positive impact for local economic growth. These trends are offering opportunities for future tourism development in Samarinda.

Increase of tourist visitation in East Kalimantan province has positive contribution to the increase of tourist in Samarinda. Grows of tourism in East Kalimantan should be viewed as a significant challenges for tourism development in Samarinda. In such a case, numerous aspects related to the improvement of tourism facility, infrastructure and attraction are needed. It is especially crucial for Samarinda city government to manage natural resources and environment following sustainable tourism principles and implementation.

\section{The tourism attractions}

The city of Samarinda geographically located at city $0^{\circ} 25^{\prime} 9.68^{\prime \prime} \mathrm{S} 117^{\circ} 9^{\prime} 13.34^{\prime \prime} \mathrm{E}$ in tropical regions of Kalimantan Island, Indonesia. Located in the centre part of the East Kalimantan, Samarinda lies on the banks of the Mahakam River $(920 \mathrm{~km})$, one of the longest rivers in Indonesia [9]. Basically, tropical forest is abundance and can be found easily in every site of Samarinda. There are opportunities to find beautiful tropical landscape and species diversity of Samarinda. According to official document regarding Samarinda Cities Spatial Planning [12], there are about 28 tourism object was found in Samarinda. It is ranging from natural to cultural object (Table 1).

The distribution and percentage of tourism attraction in Samarida city was given in Fig.3. Man-made tourism attraction has high east percentage, represent the commitment of city government to provide public facility for recreation purposes. Recreational sites and objects in the city often established by city government as part of the effort to provide recreation object for city dwellers. In urbanized area where natural resources limited and many forest has been converted into building, providing man-made tourism attraction is important. There are often policy to ensure recreational facility by city government to enhance urban community in enjoying landscape $[3,13]$.

It was followed by heritage attractions which are distributed widely in Samarinda city. It is includes old building with historical value, tradition and local knowledge. These attraction has been visited by tourist who are interested in heritages aspects. Heritage tourism is common in developing courtiers and as far it is the important segment of tourism industry in developing countries [14]. In Samarinda city, natural attraction are ranging from water-based tourism attraction (i.e. Waterfall and dam) to the park (Mulawarman Botanical garden). 

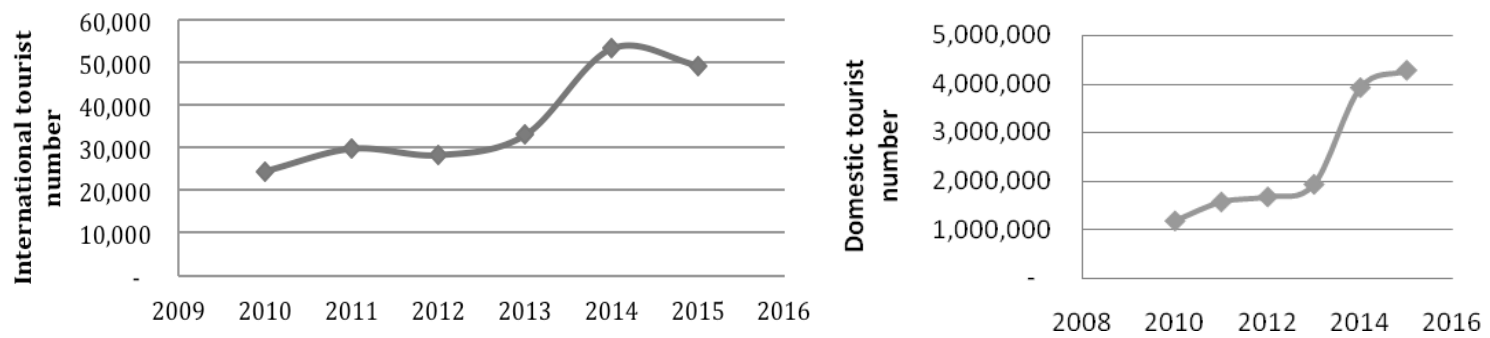

Figure 1. Trend of International and Domestic Tourist Arrival in East Kalimantan 2010 - 2015

Source: Statistic Center of East Kalimantan [10]

Table 1. Tourism Attraction in Samarinda City

\begin{tabular}{|c|c|c|}
\hline Types of attractions & Name of object & District \\
\hline \multirow{6}{*}{ Nature } & Tanah Merah Water Fall & North Samarinda \\
\hline & Mulawarman University Botanical Garden & North Samarinda \\
\hline & Pinang Seribu Tourism Object & North Samarinda \\
\hline & Batu Besaung Lake & North Samarinda \\
\hline & Benanga Reservoir & North Samarinda \\
\hline & Lubang Muda Water Fall & North Samarinda \\
\hline \multirow{11}{*}{ Man-made } & Tjius Palace Fishing Area & Sambutan \\
\hline & Mahakam Lampion Garden & Sungai Kunjang \\
\hline & Arya Ironwood house & North Samarinda \\
\hline & Alaya Hill Food Court Area & Sungai Pinang \\
\hline & Jungle Water Park & North Samarinda \\
\hline & Citra Land Water Park & Sungai Pinang \\
\hline & Bumi Sempaja Water Park & North Samarinda \\
\hline & Citra Niaga Souvenir Centre & North Samarinda \\
\hline & Home Industry Center & Sungai Pinang \\
\hline & Turmeric Rice Village & Samarinda Ilir \\
\hline & Sejati City Garden & Sungai Kunjang \\
\hline \multirow{2}{*}{ Culture and events } & Pampang Culture Tourism & North Samarinda \\
\hline & Tongkonan Makroman Tourism & Sambutan \\
\hline \multirow{9}{*}{ Heritage } & Old House Heritage Site & Samarinda Seberang \\
\hline & Weaving Village Culture tourism & Samarinda Seberang \\
\hline & Islamic Center Religious Tourism & Sungai Kunjang \\
\hline & Budhist Center Religious Tourism & Sungai Pinang \\
\hline & Tihien Le Kong Temple & Samarinda llir \\
\hline & Villa Annie Heritage Site & City of Samarinda \\
\hline & La Mahong Daeng Mangkona Sanctuary & Samarinda Seberang \\
\hline & Shiratal Mustaqim Mosque & Samarinda Seberang \\
\hline & Darussalam Great Mosque & City of Samarinda \\
\hline
\end{tabular}

These provides alternative for urban dweller to enjoy outdoors. Event has been considered few $(7 \%)$ but significantly contribute to tourism industry in Samarinda city. Event able to call potentials tourist to come and enjoy entertain, tourism program and facility in city. It is easily observed in sport and cultural event which are able to generated tourist [15].

Samarinda has potential culinary art which were few developed and promoted as one of the potential special interest tourism. More than 150 restaurant and recognized outlet has been indentified by tourism office the city. It ranging from traditional to modern food. Traditional menu from Pandang (West Sumatera), Java to
Sulawesi were available for visitors. These provides opportunities for future culinary tourism in Samarinda. Recent development of culinary tourism is positive, and it is become opportunities for numerous area to developed the area as culinary tourism destination $[16,17]$.

From the perspectives of tourism product, tourism attraction in Samarinda city can be said diverse and potentially can be used to promote more interesting city tourism program. Tourism planning development was influenced by the balance of natural resources (supply) and marked demand [3]. Supply consists of attraction accessibility, information service and accommodation. Demand was consist of tourist 
motivation. The city government o Samarinda should implement the comprehensive analysis regarding this aspect to establish Samarinda city as sustainable and competitive tourism destination.

Tourism attraction in Samarinda needs to be improved. Environmental consideration should be put as a key to enhance the quality and sustainability of natural attraction It can be observed in case of waterfall in Samarinda city. In dry season, there are no water flow the create waterfall. Environmental crisis in Samarinda city seems to be related to the impact of mining activity and forest degradation in East Kalimantan. Therefore, environmental programs should be implemented to support tourism development.

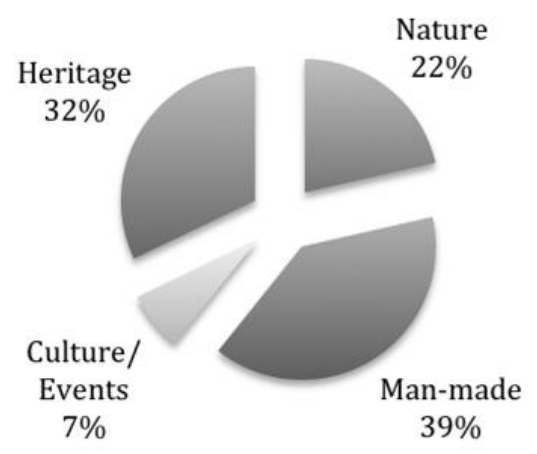

Figure 3. Tourism Attraction in Samarinda

\section{Amenity factors}

Tourism amenity is crucial in tourism destination. The destination without amenity support is often received low attention in market, and influence the low competitiveness in tourism market [3]. There are of accommodation, restaurant, health facility and business facility in Samarinda city, represent the readiness of Samarinda as tourism destinations. Samarinda has 5 and 4 star hotel, 23 guest house, 76 restaurant, 8 souvenir gallery/art shop, 3 transportation company, 5 terminal and 3 port to support tourism in Samarinda. The types and distribution of amnesties aspect of tourism in Samarida City can be classified sufficient to support tourism development. There are, however, significant actions in improvement program, especially in order to increase amenity service quality.

\section{Accessibility}

Accessibility is important aspect for tourism consideration to visit attraction. Sites with interesting attraction but poor accessibly will lead to the minimum number of tourist visitation. The gateway to the city tourism destination is from Samarinda airport and Samarinda port. There are road to acces numerous tourism object.

Effort to increase tourist invitation number in the future seems to be related to the direct flight to Samarinda. The accessibility to Samarinda are facing problem related to direct flight. As far, tourist to Samarinda should arrive in Sepinggan Airport in Balikpapan from Balikpapan (the second important city in East Kalimantan). From Balikpapan, tourist need 3 hour to Samarinda. The long land trip from Balikpapan to Samarinda as far supported by national roads.

Transportation is seems to be an important aspect for tourism competitiveness in Samarinda city. As far, number and quality service of tourist transportation was poor. Public transportation often becomes the option to access the entire destination.

\section{Attraction distribution}

The spatial distribution of tourism objet in Samarinda was given in Fig. 4. From this figure, most of the tourism amenity located in the centre of the city, while tourism attraction located in the suburb of Samarinda city. These attractions were joined with the tourism amenity in the downtown of Samarinda through provincial roads.

Based on the spatial distribution, it is clear that most of the heritage object located near the Mahakam river. These seem to be related to the past history of Samarinda, in which first activity of people in Samarinda was centered near the river. In Kalimantan, River plays an important role as corridor for transportation [5], and therefore it is common for community settlement located near the river. In South Kalimantan, Rivers is important not only for transportation, but it is also important for trading. There are opportunities for floating market in South Kalimantan [18].

Recent development of Samarinda city is flowing to the north part of the city. The development of man-made attractions also found in the north area. This development seems to be following the infrastructure development and the human population in the north area of the city. This is becoming the opportunities for the city government of Samarinda to blow the issues of tourism development to countermeasure mining activity in the suburb of the city. 


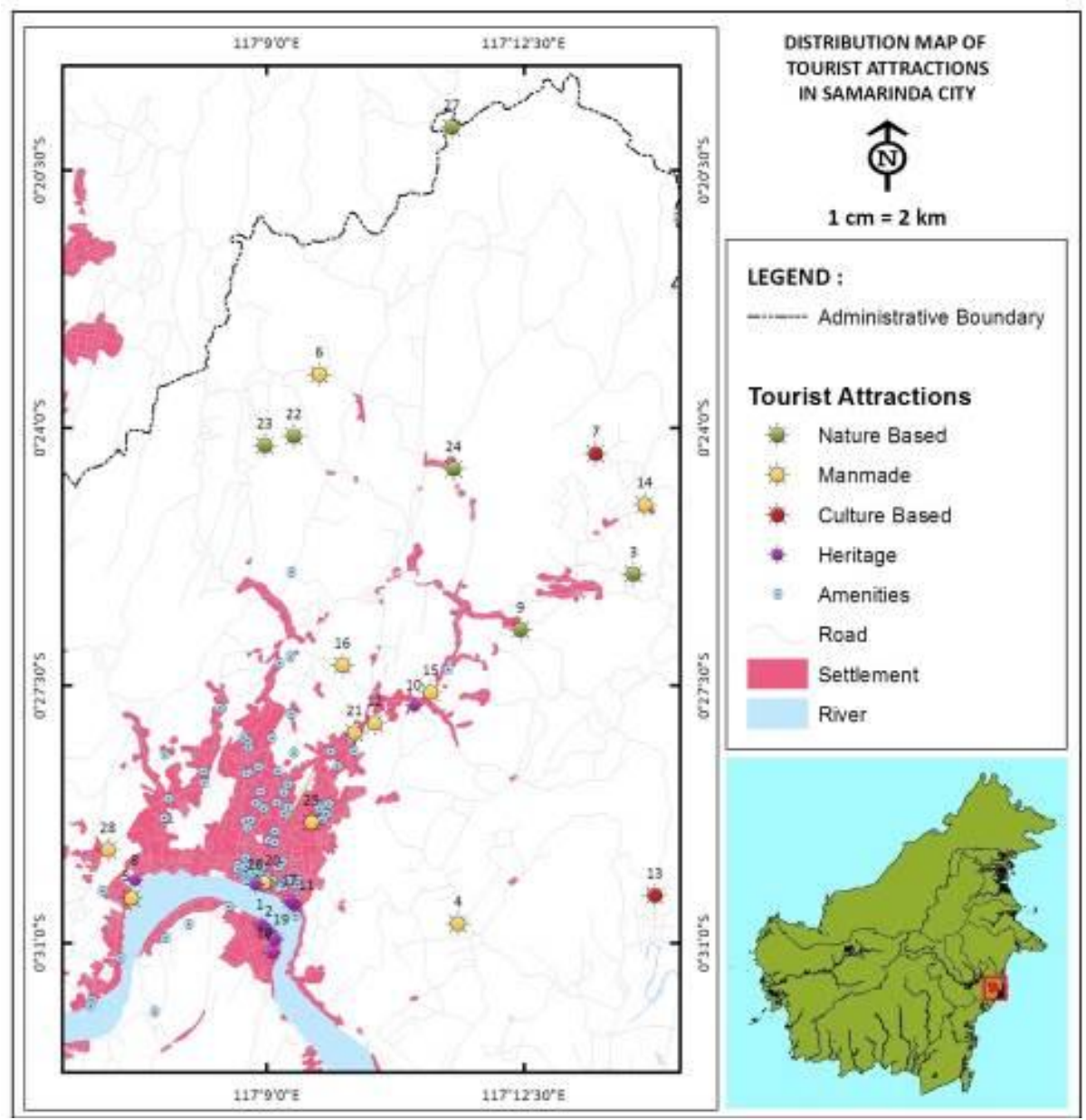

Figure 4. Distribution of Tourism Attraction in Samarinda City Area Description:
1. Old House Heritage Site Samarinda
9. Mulawarman University Botanical
19. Shiratal Mustaqim Mosque (Fig.6b) Seberang
2. Weaving Village Culture Tourism Garden (Fig. 7)
Samarinda Seberang
10. Budhist Center Religious Tourism
20. Citra Niaga Souvenir Centre
11. Tihien Le Kong Temple
12. Alaya Hill Food Court Area
21. Home Industry Center
22. Pinang Seribu Tourism Object
13. Tongkonan Makroman Tourism
23. Batu Besaung Lake
4. Tjius Palace Fishing Area
14. Jungle Water Park
24. Benanga Reservoir
25. Turmeric Rice Village Sungai Pinang
5. Mahakam Lampion Garden (Fig. 5)
15. Citra Land Water Park
16. Bumi Sempaja Water Park
26. Darussalam Great Mosque
7. Pampang Culture Tourism
17. Villa Annie Heritage Site
18. La Mahong Daeng Mangkona
27. Lubang Muda Water Fall
8. Islamic Center Religious Tourism (Fig. 6a) Sanctuary

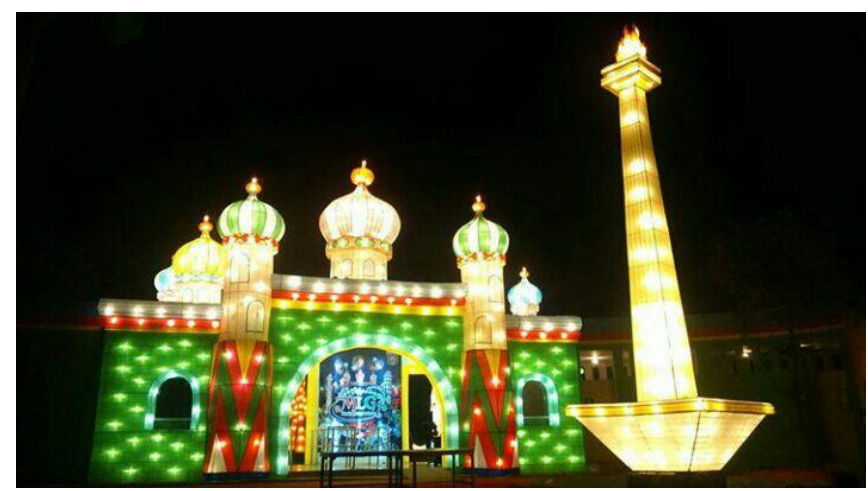

Figure 5. Mahakam Lampion Garden. Source: Personal documentation (2016) 

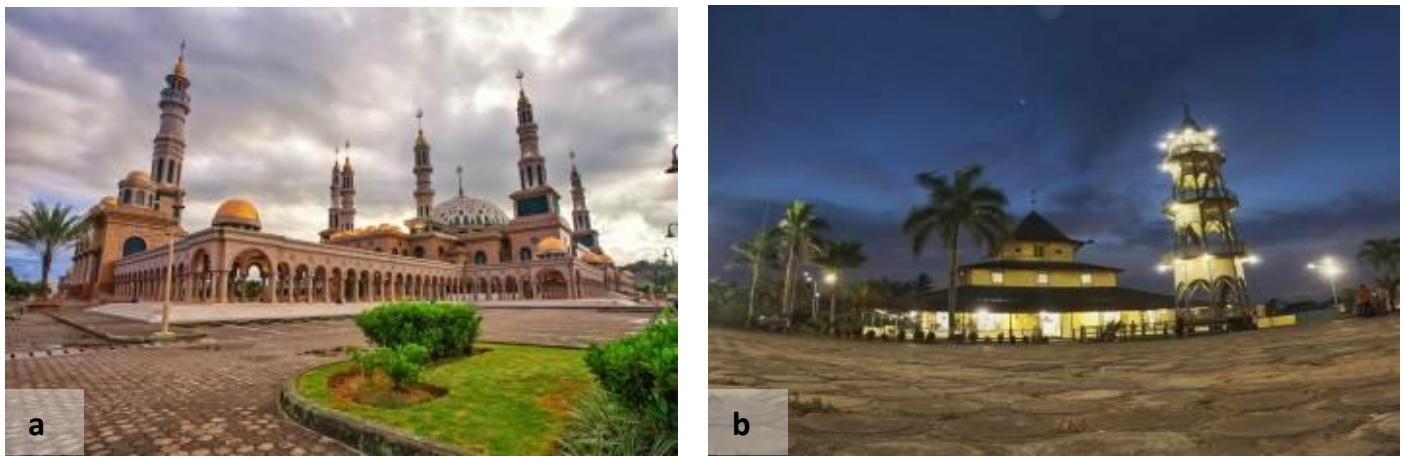

Figure 6. Religious Tourism in Samarinda. a. Islamic Center Samarinda, b. Shiratal Mustaqim mosque, Samarinda Seberang. Source: Personal documentation (2016)
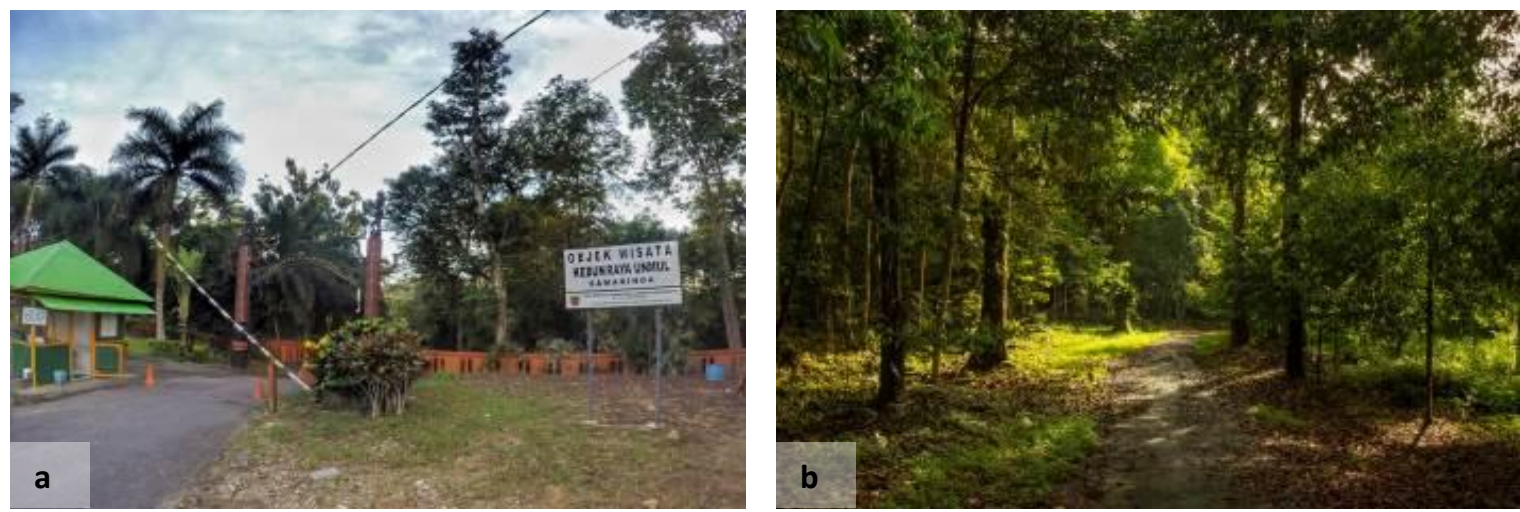

Figure 7. Mulawarman University Botanical Garden. a. Entry Gate, b. Pathway in the garden. Source: Personal documentation (2016)

\section{Future Direction of Tourism Development in Samarinda}

Samarinda has opportunities to develop tourism as one of the key to accommodate economic development, cultural preservation and environmental conservation though sustainable tourism principles. There are also opportunities to physically enhance the role of tourism development to minimize and countermeasure environmental degradation caused by mining in the city area.

Recently, degraded land after mining activity abundance in Samarinda city. The development of ex-mining land as tourism object can be done through comprehensive planning, including land evaluation, product development construction and marketing. Several aspect of ex-mining lands which are potentially becomes attraction includes (1) ex-mining sites, both in the lands area, cave, and landscapes of ex mining land (2) transportation for mining which are recently passive after mining (3) mining processing machine and building and (4) cultural aspect related to the mining which are found in surrounding mining area. These aspects can be managed as tourism product to attract tourist visitation in ex land mining area (Fig. 8).
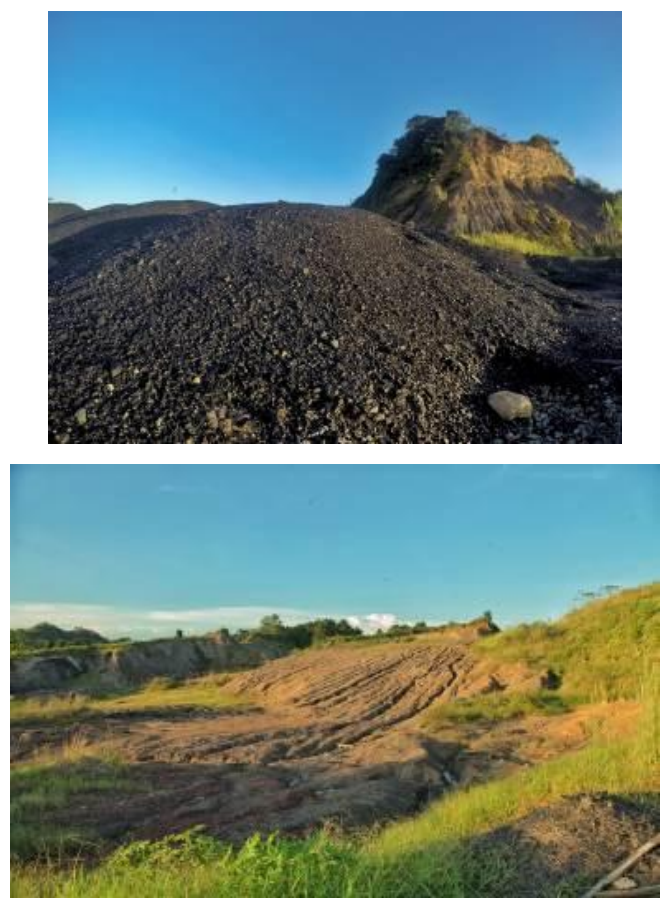

Figure 8. Post Land Mining Area. Source: Personal documentation (2016) 
The restoration of ex mining land will become the important key for tourism development. Scholar point out that restoration program in ex land mining and degraded area is the crucial strategy in environmental conservation $[19,20]$. The restoration program of ex mining land can be integrated in tourism development, and especially gaining public support for project sustainability.

The terms that have been used for Restoration is "the act of restoring to a former state or position or to an unimpaired or perfect condition". To restore means "to bring back to the original state or to a healthy or vigorous state". This usage implies returning to an original state and to a state that is perfect and healthy [21].

Land restoration comprises three components: determination of end land use, determining the main limiting factors for restoration and means of alleviating them, and finally planning and implementation of the restoration program. End land use is a prerequisite for effective land restoration. This will determine the stakeholders, the scope for restoration, the key constraints that have to be alleviated, and help define the goals for determining success. End land use has a major bearing on the degree of difficulty of the task of restoration and hence its cost [22].

\section{CONCLUSION}

Samarinda city has 28 tourism destinations, ranging from man-made, natural, cultural, heritage and event. Man-made attraction is has the highest percentage (39\%) represent the city government commitment to provides recreation object for urban dweller. The amenity was fair, but transportation should be increase to enhance tourism satisfaction. Tourist trend to Samarinda should be anticipate and become opportunities for tourism development. One of the opportunities is establishing ex mining land as tourist destination.

\section{REFERENCES}

[1] Ministry of Tourism. 2016. Report on the accountability of Tourism Ministry 2015. Ministry of Tourism, Republic of Indonesia. Jakarta.

[2] Weaver, D. and M. Oppermann. 2000. Tourism management. John Wiley and Sons. Brisbane.
[3] Gunn, C. A. and T. Var. 2002. Tourism planning: basics, concepts, cases, $4^{\text {th }} \mathrm{Ed}$. Routledge. New York and London.

[4] Putri, S. D., Soemarno and L. Hakim. 2015. Strategic management of nature-based tourism in ljen Crater in the context of sustainable tourism development. Journal of Indonesian Tourism and Development Studies 3(3), 123-129.

[5] Mackinnon, K. 1996. The ecology of Kalimantan Vol. 3. Oxford University Press. Oxford.

[6] Van Paddenburg, A., A. Bassi, E. Buter, C. Cosslett and A. Dean. 2012. Heart of Borneo: investing in nature for a Green Economy. WWF Heart of Borneo Global Initiative. Jakarta.

[7] Rahu, A. A., K. Hidayat, M. Ariyadi and L. Hakim. 2014. Management of Kaleka (traditional gardens) in Dayak community in Kapuas, Central Kalimantan. International Journal of Science and Research 3(3), 205210.

[8] Government of Samarinda. 2009. Regional Regulation on the Implementation of Tourism Business in Samarinda. Government of Samarinda City. Samarinda.

[9] Provincial Government of East Kalimantan. 2008. Main plan of regional tourism development of East Kalimantan. Province of East Kalimantan. Samarinda.

[10] Statistic Center of East Kalimantan. 2016. East Kalimantan in numbers 2016. Provincial Government of East Kalimantan. Samarinda.

[11] Ayub, S. O., Y. B. Widianarko and M. Izzati. 2015. Dominance and diversity of forest plant species growth on post coal mining soil in the Samarinda City, East Kalimantan Province, Indonesia. Journal of Biodiversity and Environmental Sciences 6(6), 29-39.

[12] Government of Samarinda. 2014. Regional Regulation No. 2: Samarinda Cities Spatial Planning. Government of Samarinda. Samarinda.

[13] Boka, R. Y. 2016. The evaluation of incentive-disincentive system in tourism development: a case study of Lake Linow development, Tomohon, North Sulawesi. Journal of Indonesian Tourism and Development Studies 4(2), 49-56.

[14] Herbert, D. T. 1995. Heritage, tourism and society. Mansell Publishing. London.

[15] Gibson, H. J., C. Willming and A. Holdnak. 2003. Small-scale event sport tourism: fans 
as tourists. Tourism management 24(2), 181-190.

[16] Long, L. M. (Ed). 2004. Culinary tourism. University Press of Kentucky. Lexington.

[17] Sukenti, K., L. Hakim, S. Indriyani, Y. Purwanto and P. J. Matthews. 2016. Ethnobotanical study on local cuisine of the Sasak tribe in Lombok Island, Indonesia. Journal of Ethnic Foods 3(3), 189-200.

[18] Ellyn, N., M. S. Djati, T. Hidayat and L. Hakim 2015. Tourist profiles and perception as a basic planning for sustainable tourism development Lok Baitan Floating Market, South Kalimantan. IOSR Journal of Environmental Science, Toxicology and Food Technology 9(11), 11-16.

[19] Sengupta, M. 1993. Environmental impacts of mining monitoring, restoration, and control. CRC Press. Boca Raton, Florida.

[20] Cooke, J. A. and M. S. Johnson. 2002. Ecological restoration of land with particular reference to the mining of metals and industrial minerals: A review of theory and practice. Environmental Reviews 10(1), 4171.

[21] Bell, R. W. 2002. Restoration of degraded landscapes: principles and lessons from case studies with salt-affected land and mine revegetation. CMU Journal 1(1), 1-21.

[22] Kuter, N. 2013. Reclamation of degraded landscapes due to opencast mining. In: Özyavuz, M. (Ed). Advances in Landscape Architecture. Intech. Available at: http://www.intechopen.com/books/advanc es-in-landscape-architecture/reclamationof-degraded-landscapes-due-to-opencastmining. 